Correspondence

Weibo Song wsong@ouc.edu.cn

\section{Systematic position of Discocephalus-like ciliates (Ciliophora: Spirotrichea) inferred from SSU rDNA and ontogenetic information}

\author{
Chen Shao, ${ }^{1}$ Weibo Song, ${ }^{1,2}$ Lifang Li, ${ }^{1}$ Alan Warren, ${ }^{3}$ \\ Khaled A. S. Al-Rasheid, ${ }^{4}$ Saleh A. Al-Quraishy, ${ }^{4}$ Saleh A. Al-Farraj ${ }^{4}$ \\ and Xiaofeng Lin $^{2}$ \\ ${ }^{1}$ Laboratory of Protozoology, Ocean University of China, Qingdao 266003, PR China \\ ${ }^{2}$ Laboratory of Protozoology, College of Life Science, South China Normal University, Guangzhou \\ 510631, PR China \\ ${ }^{3}$ Department of Zoology, Natural History Museum, Cromwell Road, London SW7 5BD, UK \\ ${ }^{4}$ Zoology Department, King Saud University, PO Box 2455, Riyadh 11451, Saudi Arabia
}

\begin{abstract}
The Prodiscocephalus-like ciliates, or discocephalines, are cephalized organisms that are traditionally considered to be hypotrichs (sensu lato) but whose precise systematic position has long been uncertain. The main reasons for this are that these organisms exhibit several intermediate morphological and morphogenetic features and that hitherto none has been investigated using molecular methods. In the present study, the cortical development of Prodiscocephalus borrori was observed during binary division and this can be summarized as follows: (i) in the parental adoral zone of membranelles, only the posterior end is renewed by dedifferentiation of the old structures; (ii) the oral primordium in the opisthe occurs de novo on the cell surface as seen in other typical stichotrichs; (iii) in both dividers, the undulating membranes anlage does not split longitudinally in the usual way but, instead, divides transversely to form the paroral and endoral membranes; (iv) usually seven frontoventral transverse cirral anlagen are formed in the primary mode which then divide into two sets, one each for the proter and opisthe; (v) both left and right marginal rows divide into two parts, thus giving rise to a post-lateral marginal segment at the posterior end of each; (vi) invariably five caudal cirri are formed at the posterior end of the three rightmost dorsal kinety anlagen. Thus, it was found that, like other related discocephalines, $P$. borrori exhibits more similarities to stichotrichs than to euplotids. Based on a combination of morphological and morphogenetic data, a phylogenetic tree was constructed which suggests that the discocephalines group within the stichotrichs and separate from the euplotids. In addition, the complete small-subunit rRNA gene (SSU rDNA) of $P$. borrori was sequenced and analysed. In the resulting SSU rDNA tree, the discocephalines represent an intermediate group between the euplotids and the Stichotrichia-Oligotrichia-Choreotrichia assemblage, albeit with low bootstrap support. From these data, we conclude that the discocephalines might be a divergent, or possibly an ancestral, group within the Stichotrichia. Furthermore, our findings further support the suggestion that these organisms should be considered as a distinct order, i.e. Discocephalida Wicklow, 1982, in the subclass Stichotrichia Small \& Lynn, 1985.
\end{abstract}

Abbreviations: AZM, adoral zone of membranelles; BI, Bayesian inference; DK, dorsal kinety; FVT, frontoventral transverse; ML, maximum-likelihood; OP, oral primordium; s. I., sensu lato; SSU, small subunit; UM, undulating membranes.

The GenBank/EMBL/DDBJ accession number for the SSU rDNA sequence of Prodiscocephalus borrori is DQ646880.

Details of reference sequences used in this analysis are available as supplementary material with the online version of this paper.

\section{INTRODUCTION}

The discocephaline ciliates, which are characterized by their cephalized body shape, psammophilic habitat and unique combination of morphological features, are one of the most confused groups within the traditional 'hypotrichs' sensu lato (s. l.) (i.e. including both stichotrichs and euplotids) regarding their phylogenetic relationships. Corliss (1979) regarded the discocephalines as a genus-complex which he tentatively placed in the family Euplotidae, order 
Hypotrichida. Jankowski (1979), however, treated them as a family within the order Sporadotrichina. Subsequently, Wicklow (1982) upgraded them to suborder within the order Hypotrichida (s. l.), whereas Small \& Lynn (1985) classified them as a suborder in the Euplotida. Tuffrau (1986) assigned them to Hypotrichida (s. l.) and as a suborder along with Euplotina, Stichotrichina and Sporadotrichina. de Puytorac et al. (1993) established the order Discocephalida within the subclass Oxytrichia (class Hypotrichea), which was subsequently accepted by Tuffrau \& Fleury (1994). More recently, Lynn \& Small (2000) retained the arrangement they suggested previously (Small \& Lynn, 1985), with Discocephalina as a sister group to Euplotina in the order Euplotida.

There are a number of reasons for this confusion: (i) patterns of morphogenesis within this group are poorly understood, with only two discocephaline taxa, Marginotricha and Discocephalus, having been studied morphogenetically; (ii) there is a complete absence of molecular data; (iii) many morphological and morphogenetic features present in discocephalines are shared by different ranks of hypotrichs and/or stichotrichs (Wicklow, 1982; Foissner, 1996; Lin et al., 2004).

In the spring of 2005, a population of Prodiscocephalus borrori (Wicklow, 1982) was isolated from marine sediments near Qingdao, China, enabling studies of its morphogenesis to be carried out, its small-subunit rRNA gene (SSU rDNA) to be sequenced and its phylogenetic position to be analysed. The aims of the present paper are (i) to increase our knowledge and understanding of morphogenesis in discocephalines and (ii) to re-evaluate the systematic position of the discocephalines based on morphological, morphogenetic and molecular data.

\section{METHODS}

Morphological and morphogenetic studies. Samples were collected on 8 May 2005 from the surface of sandy littoral sediments (up to $5 \mathrm{~cm}$ deep) in Jiaozhou Bay near Qingdao, China $\left(120^{\circ} 18^{\prime} \mathrm{E}\right.$ $36^{\circ} 04^{\prime} \mathrm{N}$ ). Isolated specimens were maintained in the laboratory for about 1 week as uniprotistan cultures (water temperature about $20{ }^{\circ} \mathrm{C}$, salinity $\sim 30 \%$ ) in Petri dishes for observation and further studies. Cells in division were selected and then impregnated using the protargol method (Wilbert, 1975). Drawings were made using a camera lucida at $\times 1250$ magnification. To illustrate the changes during morphogenetic processes, parental cirri are depicted in outline, whereas new ones are shaded black. Terminology and systematics are mainly according to Wicklow (1982) and Lynn \& Small (2000).

SSU rDNA sequence and phylogenetic analyses. Genomic DNA extraction, PCR amplification of the SSU rDNA, cloning and sequencing were performed according to Li \& Song (2006). The nucleotide sequences used in this study are available from the GenBank/EMBL/DDBJ databases, including 21 species sequenced by the senior author's laboratory (see Supplementary Table S1, available in IJSEM Online).

Sequences were aligned using CLUSTAL W v. 1.80 (Thompson et al., 1994) and then the alignment was refined through consideration of conserved secondary structures. A $50 \%$ majority-rule Bayesian inference (BI) tree was constructed with MrBayes 3.1.2 (Ronquist \& Huelsenbeck, 2003) using the GTR $+\mathrm{G}+\mathrm{I}$ evolutionary model indicated by Mrmodeltest v.2 (Nylander, 2004). The chain length for our analysis was 10000000 generations, with trees sampled every 100 generations. The first 2500000 generations were discarded as burn-in.

A maximum-likelihood (ML) tree was constructed with PAUP (v. 4.0b10) (Swofford, 2002) using the $\operatorname{TrN}+\mathrm{I}+\mathrm{G}$ evolutionary model selected by Modeltest (Posada \& Crandall, 1998) and an input file created by performing an accelerated likelihood surface exploration (Nixon, 1999; Vos, 2003) with the program PAUPRat (Sikes \& Lewis, 2001). A $50 \%$ majority-rule consensus ML tree was derived from the output of 200 trees generated by PAUP operating on the input file from PAUPRat.

The topologies of the BI and ML trees were almost identical. Therefore, they were merged into a single tree for purposes of illustration. This tree was formatted with MEGA (Kumar et al., 2004) and exported from it as a graphics file for construction of the finished figure. (a)

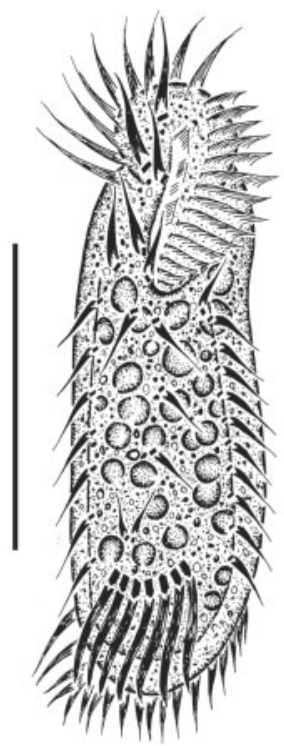

(b)

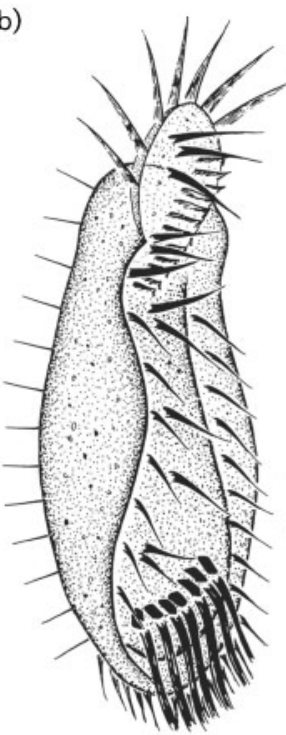

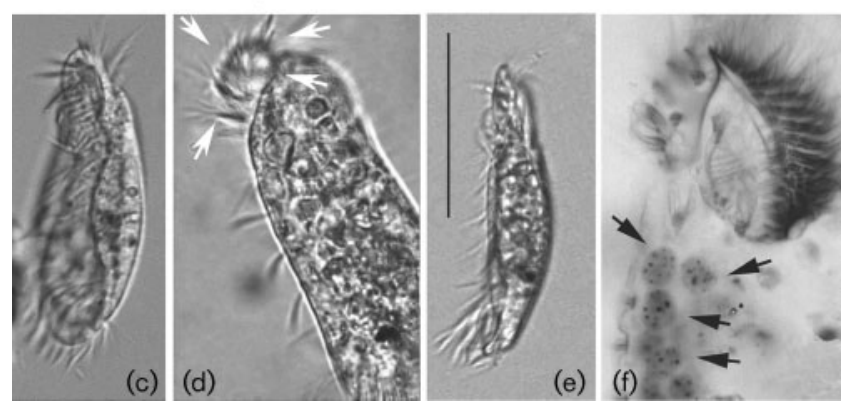

Fig. 1. $P$. borrori in vivo (a-e) and after protargol impregnation ( $f$ ) (after Lin et al. 2004, with permission). (a) Ventral view of a typical individual. (b, c) Ventral-lateral views. (d) Dorsal view, to show the discoid 'head' (arrows). (e) Lateral view. (f) Anterior portion, to show macronuclear nodules (arrows). Bars, $40 \mu \mathrm{m}$ (a; also applies to b) and $50 \mu \mathrm{m}$ (e; also applies to $\mathrm{c}, \mathrm{d}, \mathrm{f}$ ). 


\section{RESULTS}

\section{Morphology of Prodiscocephalus borrori (Wicklow, 1982) Lin et al., 2004 (Figs 1 and 2a-c)}

The population of $P$. borrori studied here corresponds very closely with the population reported by Lin et al. (2004), hence a detailed description is unnecessary. As Figs 1 and $2(\mathrm{a}-\mathrm{c})$ demonstrate, this species has a slender body shape, prominent transverse cirri, invariably 12 frontoventral cirri that are sparsely distributed and one marginal row on each side. It should also be noted that two short fragments with close-set cirri (post-lateral left and right marginal cirri; PLMC, PRMC in Fig. 2b) are located posterior to the left and right marginal rows, respectively, and that the five caudal cirri are arranged in three rows with the pattern of $1: 2: 2$ from left to right (arrows in Fig. 2b). By contrast, Lin et al. (2004) reported that the number of caudal cirri is variable, but this was almost certainly due to confusion with the post-lateral right marginal cirri (PRMC in Fig. 2b)
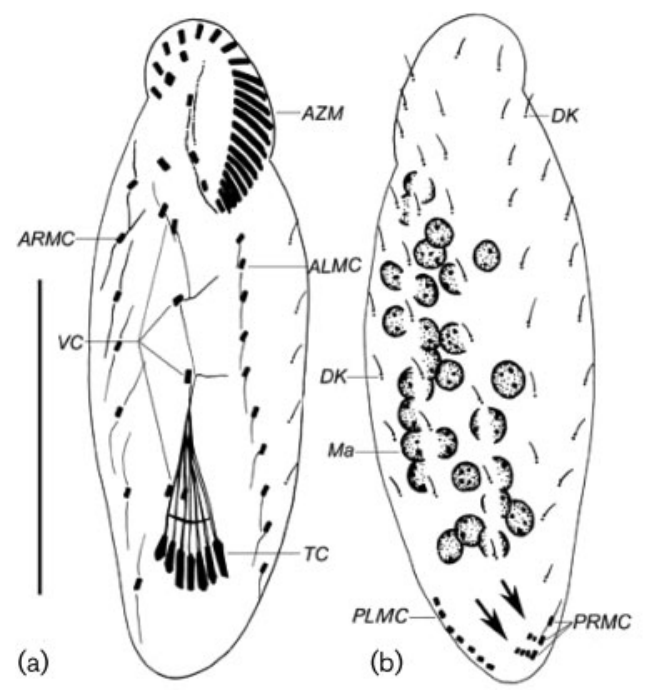

(c)
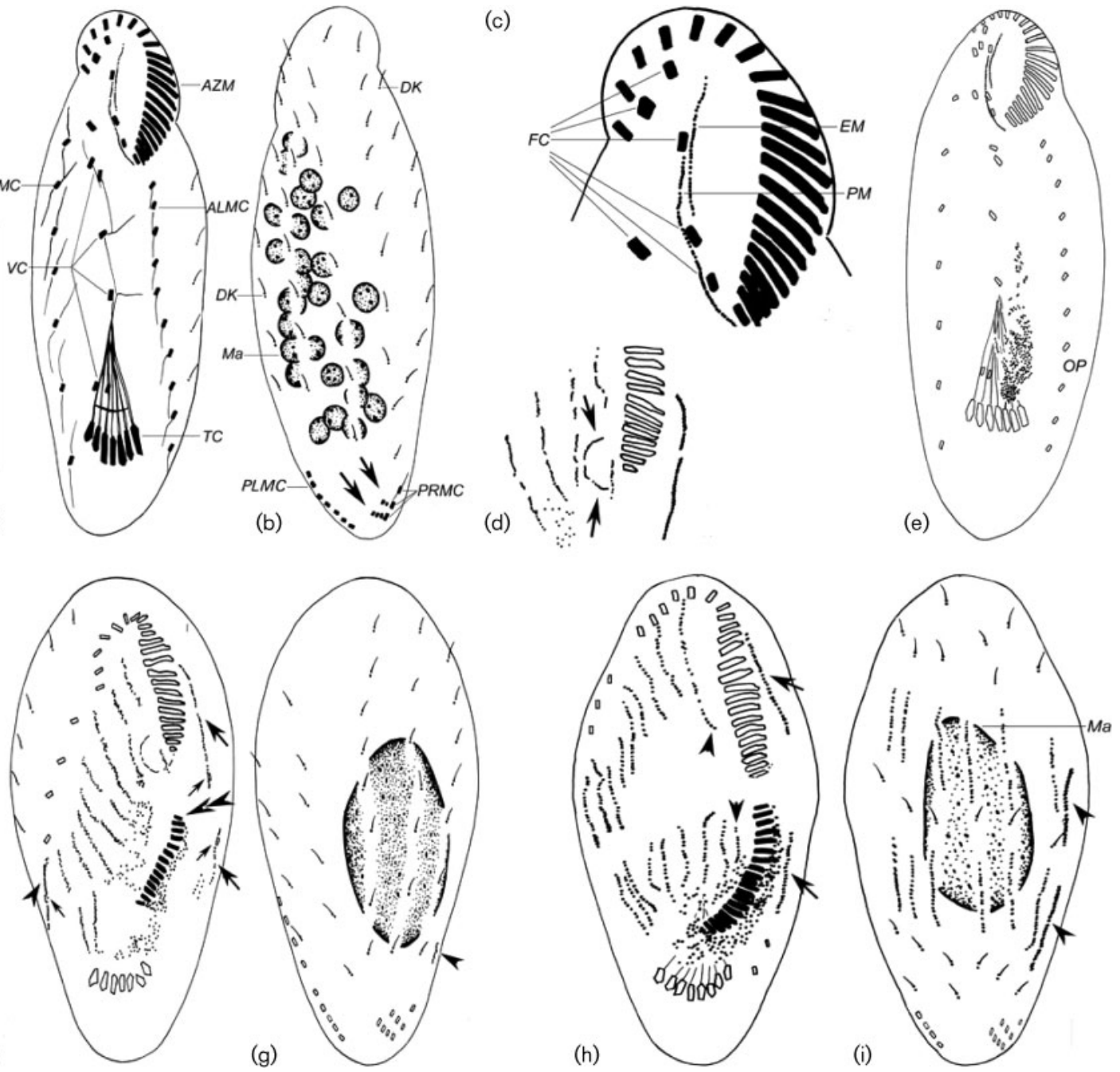

Fig. 2. P. borrori before division $(a-c)$ and in the early stages of morphogenesis $(d-i)$ after protargol impregnation. $(a, b)$ Ventral and dorsal views of the same specimen, to demonstrate the general pattern of the infraciliature. Arrows in (b) mark the caudal rows. (c) Infraciliature of the anterior portion of the cell. (d) Detail of ventral view in an early divider, to show the curved structure (UM-anlage; arrows). (e) Ventral view of a divider in very early stage. ( $f, g)$ Ventral and dorsal views of the same specimen, to show the right (arrowheads) and left (large arrows) marginal anlagen; the double arrowhead marks the newly formed OP and small arrows show the old marginal cirri. $(\mathrm{h}, \mathrm{i})$ Slightly later stage, ventral and dorsal views of the same cell; note that the FVTand DK anlagen are completely formed in both dividers. Arrows in (h) show the left marginal row anlagen, arrowheads mark the UM-anlage; arrowheads in (i) depict the right marginal row anlagen. ALMC, Anterior left marginal cirri; ARMC, anterior right marginal cirri; AZM, adoral zone of membranelles; DK, dorsal kinety; EM, endoral membrane; FC, frontal cirri; Ma, macronuclear nodule; OP, oral primordium; PLMC/PRMC, post-lateral left/right marginal cirri; PM, paroral membrane; TC, transverse cirri; VC, ventral cirri. Bar, $40 \mu \mathrm{m}$. 
being erroneously counted as caudal cirri. These two types of cirri can be recognized clearly during morphogenesis but are almost impossible to distinguish in non-dividing cells.

\section{Morphogenesis of the Qingdao population of $\boldsymbol{P}$. borrori during binary fission (Figs $2 d-i, 3,4$ and 5 )}

Oral primordia (OP). P. borrori demonstrates an epiapokinetal pattern of morphogenesis with respect to the formation of the OP in the opisthe and a mixture of typical stichotrich and euplotid modes regarding the development of the somatic ciliature. The main processes are as follows. The OP appears on the cell surface below the equatorial level (Fig. 2e). Soon after, the membranelles are generated, beginning at the anterior end of the OP posteriad, and these will form the adoral zone of membranelles (AZM) of the opisthe (Fig. 2f, double arrowheads; Fig. 4d, arrow). In the early stage, the anterior portion of the old undulating membranes (UM) appears to be resorbed, whereas the posterior part appears to dedifferentiate and develops into a curved structure that will be the anlage for the UM (arrows in Figs $2 \mathrm{~d}$ and $4 \mathrm{c}$ ). Later, the leftmost frontal cirrus is formed and separates from the UM anlage in both dividers (Fig. 3a, arrows; Fig. 4f, i, arrow). When most of the new membranelles are formed in the OP, the proximal end of the parental AZM begins to disorganize (Fig. 3a, arrowhead).

The endoral and paroral membranes, which are derived from the UM-anlage by segmentation, are initially confluent but then separate from each other as the latter arches to the left (Fig. $3 \mathrm{~g}$, arrows and double arrowheads; Fig. 5g, h, arrow).
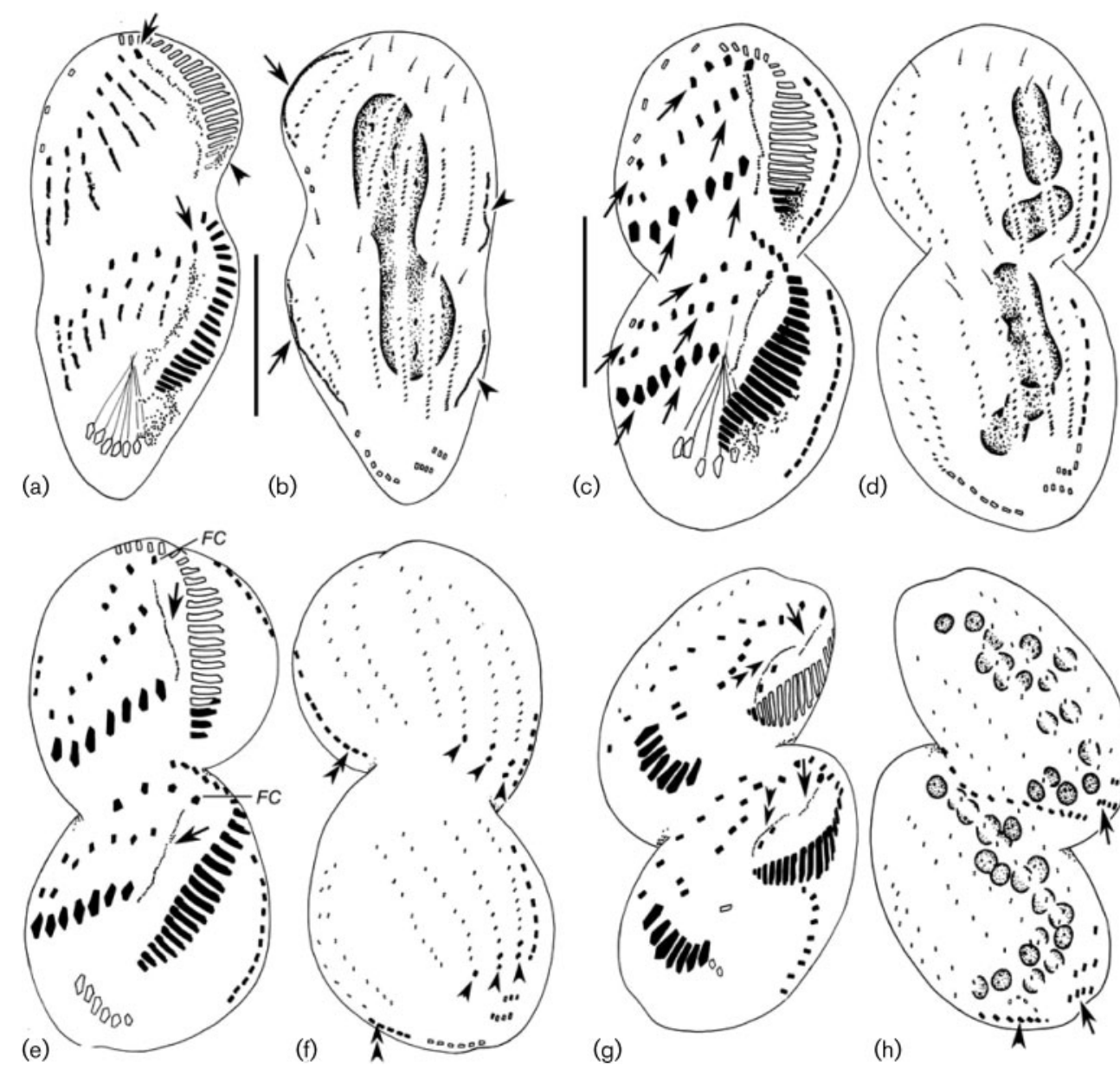

(g)

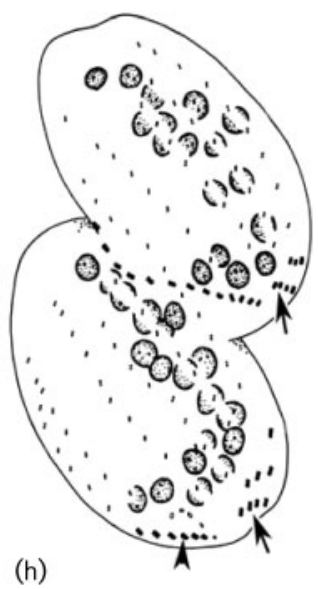

Fig. 3. Middle and late morphogenetic stages in P. borrori. (a) Ventral view, to show the UM-anlage generating the anteriormost FC in both dividers (arrows) and the FVT-anlagen beginning to segment. Note the proximal end of the old AZM beginning to dedifferentiate (arrowhead). (b) Dorsal view of the same cell as in (a), to show the left (arrows) and right (arrowheads) marginal row anlagen. (c, d) Ventral and dorsal views of the same specimen, showing the FVT cirri (arrows in c). (e, f) Ventral and dorsal views of the same cell; note the UM-anlage is still single-rowed (arrows), and the caudal cirri are differentiated from DK anlagen (arrowheads). Double arrowheads in (f) mark the post-lateral marginal cirri. (g) Ventral view, showing the separated paroral (double arrowheads) and endoral (arrows) membranes. (h) Dorsal view of the same specimen as in (g); arrows mark five caudal cirri, arrowhead shows the post-lateral marginal cirri. FC, Frontal cirri. Bars, $40 \mu \mathrm{m}$. 


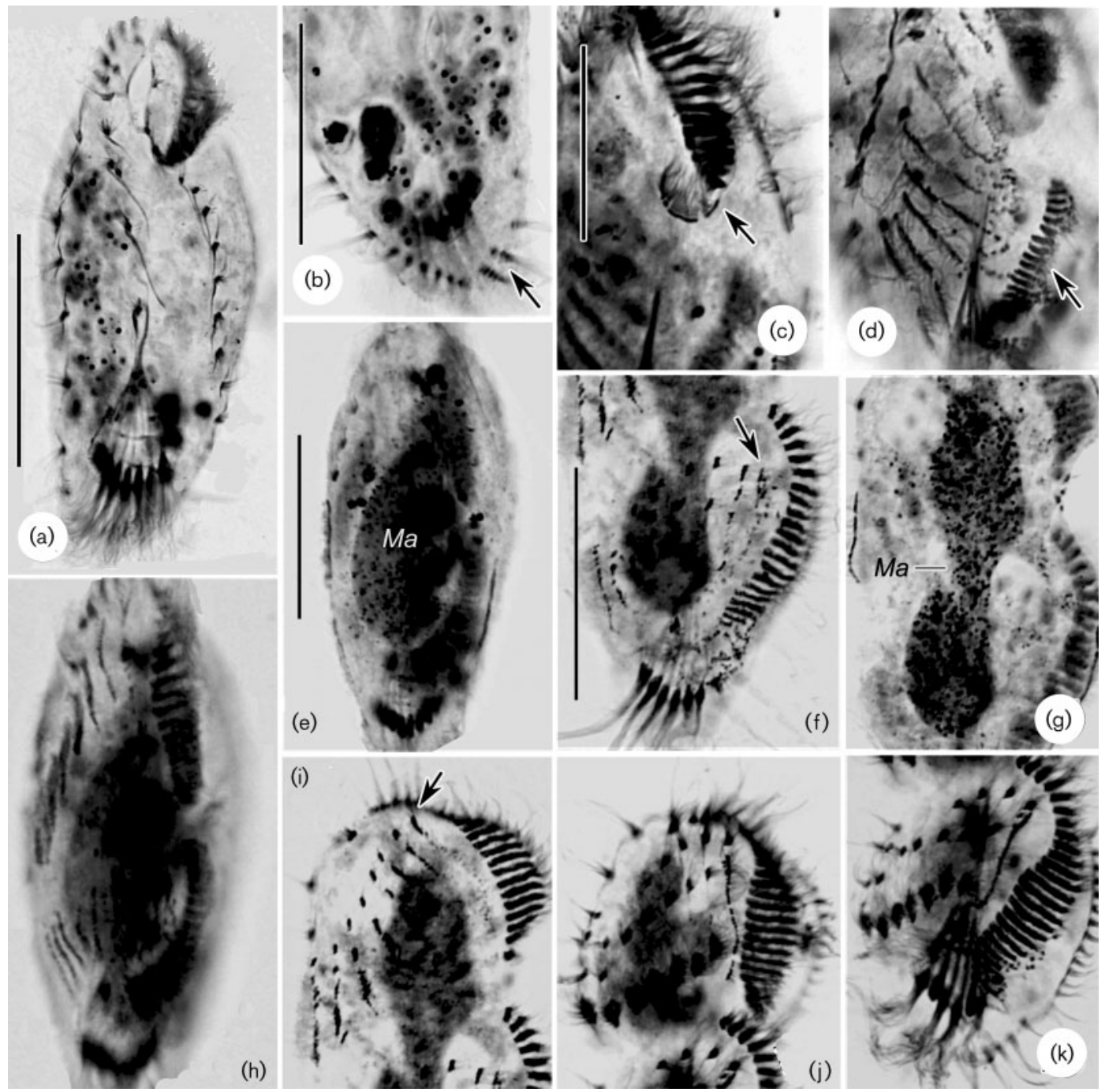

Fig. 4. Photomicrographs of the morphology $(a, b)$ and morphogenesis $(c-k)$ of $P$. borrori after protargol impregnation. (a) Ventral view of a non-dividing cell. (b) Detail of the posterior portion of the cell. Note the caudal cirri (arrow). (c) Ventral view of the proter in an early division stage, to demonstrate the curved UM-anlage (arrow). (d) Ventral view, showing the new membranelles formed in the OP (arrow). (e) Showing the fusion of the macronuclear nodules into a single mass (Ma). ( $f$ ) Ventral view of a mid-stage divider, to show the UM-anlage generating the anteriormost frontal cirrus in the opisthe (arrow). (g) The macronucleus (Ma) in division. (h) Ventral view of an early divider, showing the streaks of the FVT-anlagen. (i) Ventral view; note the anteriormost frontal cirrus developing from the UM-anlage in the proter (arrow). ( $j, k$ ) Showing the segmentation of the FVTanlagen in both proter (j) and opisthe (k). Bars, $40 \mu \mathrm{m}(\mathrm{a}, \mathrm{b}, \mathrm{e}, \mathrm{f})$ and $20 \mu \mathrm{m}$ (c; also applies to d). Note that ( $\mathrm{g}-\mathrm{k})$ are the same magnification as (f).

Cirral streaks. Seven or eight frontoventral transverse (FVT) anlagen are generated to the right of the parental oral apparatus as oblique streaks, the old structures apparently not being involved in the formation of these new anlagen (Figs $2 \mathrm{f}$ and $4 \mathrm{~d}$ ). These streaks appear initially as a single set (primary pattern) that subsequently divides into two groups (Fig. 2h). Finally, the FVT-anlagen are segregated in the pattern of $3: 3: 3: 2: 2: 3: 2$ from left to right (Fig. 3a, c, showing the specimens with only seven cirral primordia). Thus, with the frontal cirrus from the anterior end of the UM anlage, a total of 19 FVT-cirri are formed. It is therefore assumed that, in those cells with eight FVT-anlagen, the extra cirri produced by the additional anlage are resorbed prior to the completion of the division process.

Marginal and dorsal kineties (DK) anlagen. The new marginal rows are generated intrakinetally in the usual manner for stichotrichs (Figs $2 \mathrm{f}-\mathrm{i}$ and 3 ). Nevertheless, at the very late stage, about four to eight cirri in the posterior portion of the left marginal row and three or four cirri in 


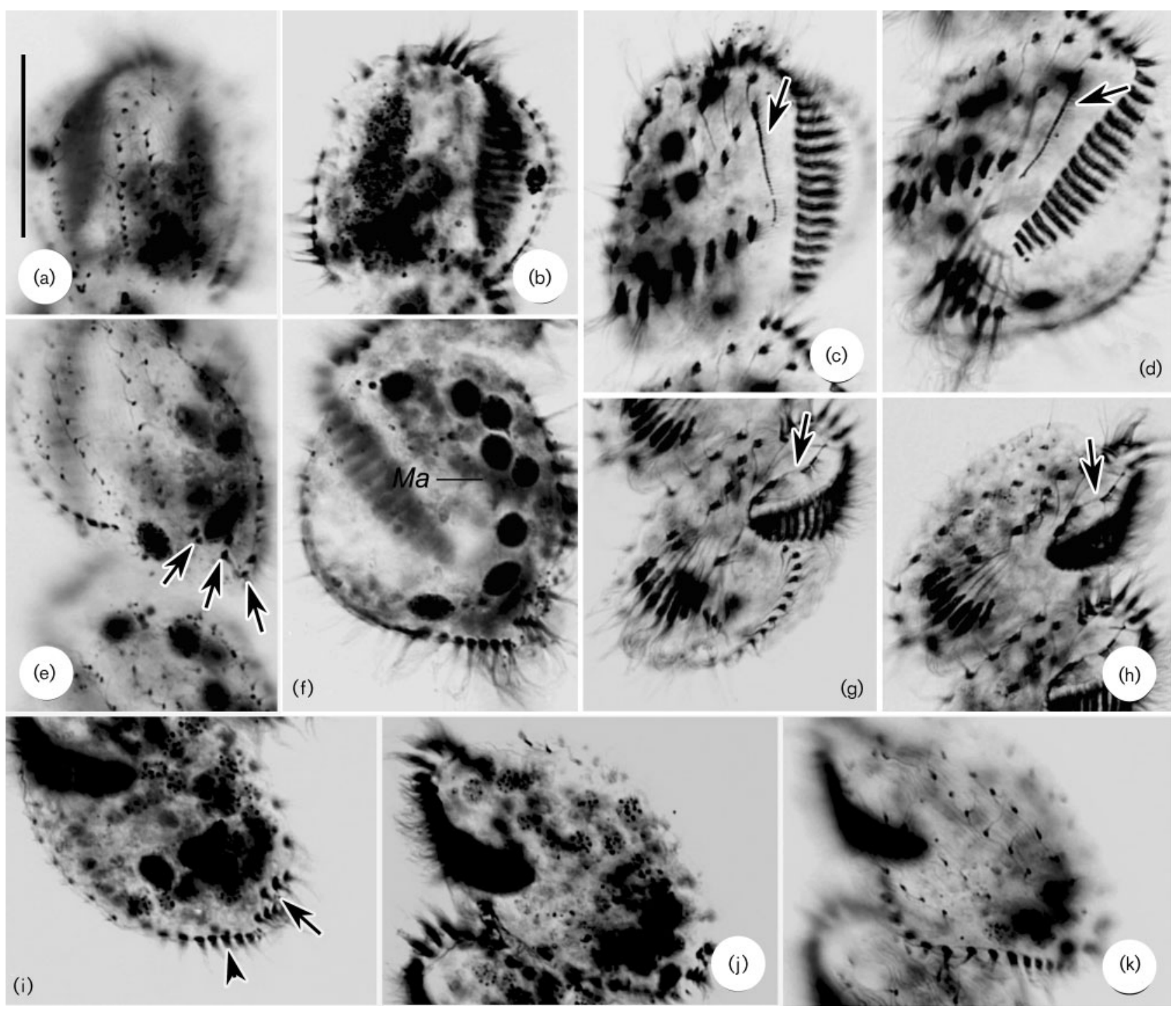

Fig. 5. Photomicrographs of $P$. borrori during morphogenesis. $(a, b)$ Dorsal and ventral views; note that the DK anlagen stretch to both ends of the cell. (c-e) Ventral (c, d) and dorsal (e) views of the same divider. Note the single-rowed UM-anlage in both proter (arrow in c) and opisthe (arrow in d). Arrows in (e) showing five caudal cirri differentiated from DK4 (1), DK5 (2) and DK6 (2), respectively. (f) Macronuclear nodules (Ma) in division having previously been fused into a single mass. ( $g, h$ ) Ventral views of the same cell. Note that the endoral and paroral membranes develop from the UM-anlage in the opisthe (arrow in $\mathrm{g}$ ) and proter (arrow in h). (i-k) Dorsal views of a divider just before separation (focusing on different levels). The arrow in (i) points to the caudal cirri; arrowhead shows the left post-lateral marginal cirri. Note the macronuclear nodules (j) and dorsal kineties (k). Bar, $40 \mu \mathrm{m}$

the posterior portion of the right marginal row migrate to the dorso-marginal side, giving rise to the post-lateral left and right marginal fragments, respectively (Fig. 3f, double arrowheads; Figs $3 \mathrm{~h}$ and 5i, arrowhead).

The formation of dorsal kineties exhibits a urostylid (i.e. secondary) mode in that the two sets of DK anlagen are generated intra-kinetally within the old rows in both dividers (Figs $2 \mathrm{i}$ and $3 \mathrm{~b}, \mathrm{~d}$ ). In contrast, the five caudal cirri are generated in a euplotid mode, i.e. the three rows are formed at the posterior ends of the three rightmost dorsal kineties in the pattern of $1: 2: 2$ (Fig. 3f, arrowheads; Figs $3 \mathrm{~h}$ and 5e, arrows; Fig. 5i, arrow).

All macronuclear nodules (Ma) fuse into a single mass prior to division in the usual way.

\section{SSU rDNA sequence analysis}

The SSU rDNA of P. borrori was newly sequenced (length 1769 nucleotides). Alignment of this sequence clearly showed similarities in primary structure and $\mathrm{G}+\mathrm{C}$ 


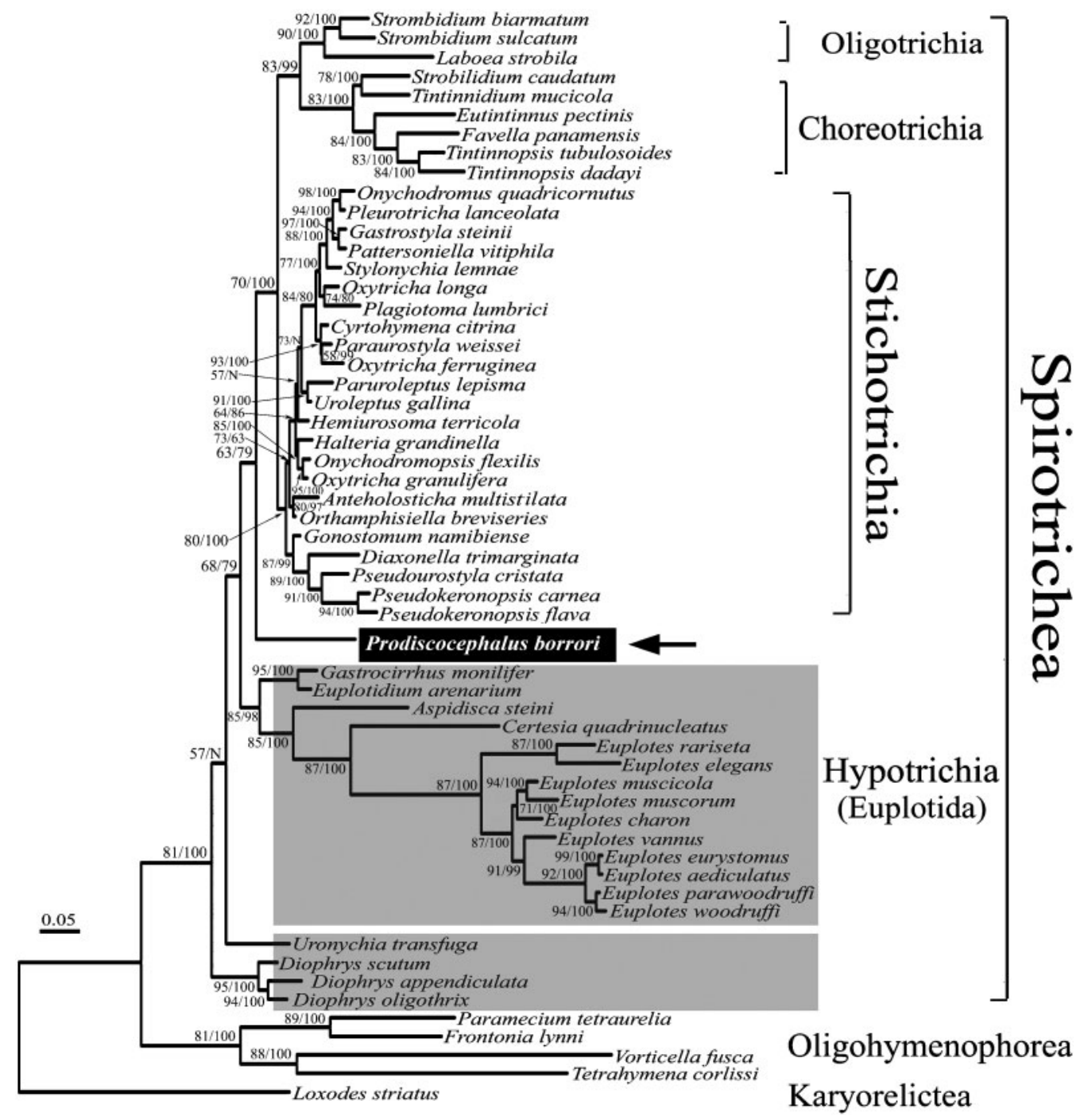

Fig. 6. Bayesian tree inferred from nucleotide sequences of the SSU rDNA. Numbers at nodes represent bootstrap values (\%) from 1000 replicates: the first number is the Bayesian credibility value using the MrBayes algorithm and the second is from the $\mathrm{ML}$ method; $\mathrm{N}$, not significant. Loxodes striatus was selected as the outgroup taxon. Evolutionary distance is represented by the branch length to separate the species in the figure. Bar, 5 substitutions per 100 nucleotide positions.

content $(44.6 \mathrm{~mol} \%)$ to other spirotrichous ciliates (Sogin \& Elwood, 1986; Schlegel et al., 1991). The structural similarities were $78.07-88.83 \%$ between $P$. borrori and euplotids and $86.05-89.91 \%$ compared with stichotrichs.

\section{Bayesian analyses based on the sequence of the SSU} rDNA. The phylogenetic trees constructed using different methods gave identical topological structure, hence only one tree is presented here (Fig. 6). The analyses provide moderate to high bootstrap support for the monophyly of Stichotrichia (80\% BI, $100 \% \mathrm{ML})$ and most of Hypotrichia ( $85 \%$ BI, $98 \% \mathrm{ML}$ ), i.e. all typical euplotids except the Diophrys-Uronychia assemblage, which branches from the spirotrichous clade at a deep level though with low bootstrap support. The monophyly of each of the other two spirotrich subclasses, Choreotrichia ( $83 \%$ BI, $100 \%$ ML) and Oligotrichia (90\% BI, $100 \% \mathrm{ML}$ ), is also confirmed, as expected. P. borrori is placed between the Stichotrichia-Choreotrichia-Oligotrichia clade and the Hypotrichia clade and is sister to the former.

\section{DISCUSSION}

Traditionally, the discocephalines have been separated from the stichotrichs and the euplotids by their cephalized body shape, highly differentiated infraciliature (which is similar to that of oxytrichids) and extremely welldeveloped fibre system and by being invariably psammophilic (Dragesco, 1960, 1965; Wicklow, 1982; Curds \& Wu, 1983; Lin et al., 2004). There is little agreement, however, 
Table 1. Comparison of morphogenetic characteristics among three higher hypotrichous groups

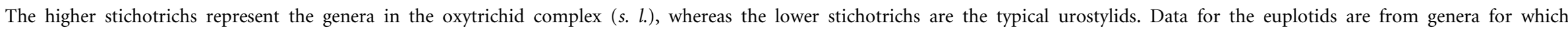
morphogenesis is well characterized (e.g. Euplotes, Diophrys, Uronychia and Aspidisca, respectively abbreviated as Eup., Dio., Uro. and Asp.).

\begin{tabular}{|c|c|c|c|c|c|c|}
\hline Character & Higher stichotrichs & Lower stichotrichs & Euplotids & $\begin{array}{c}\text { Discocephalus } \\
\text { ehrenbergi }\end{array}$ & $\begin{array}{l}\text { Marginotricha } \\
\text { faurei }\end{array}$ & $\begin{array}{c}\text { Prodiscocephalus } \\
\text { borrori }\end{array}$ \\
\hline Fate of old AZM & Completely retained & Mostly renewed & $\begin{array}{l}\text { Retained (Eup. and Asp.) } \\
\text { or partly renewed (Dio.) }\end{array}$ & Completely retained & Partly renewed & Partly renewed \\
\hline Fate of old UM & Completely renewed & Completely renewed & $\begin{array}{l}\text { Retained (Eup. and Asp.) } \\
\text { or completely renewed } \\
\text { (Dio.) }\end{array}$ & Completely renewed & Completely renewed & Completely renewed \\
\hline $\begin{array}{l}\text { Origin of the opisthe's } \\
\text { OP }\end{array}$ & On cell surface & On cell surface & $\begin{array}{l}\text { Within a subsurface } \\
\text { pouch, beneath the } \\
\text { pellicle }\end{array}$ & On cell surface & On cell surface & On cell surface \\
\hline $\begin{array}{l}\text { FVT-cirral anlagen, } \\
\text { number }\end{array}$ & 5 FVT-anlagen & More than 5 & 5 FVT-anlagen & More than 5 & More than 5 & More than 5 \\
\hline $\begin{array}{l}\text { Type of development of } \\
\text { FVT-anlagen }\end{array}$ & $\begin{array}{l}\text { Almost absolutely } \\
\text { secondary }\end{array}$ & $\begin{array}{l}\text { Mostly secondary, less } \\
\text { commonly primary }\end{array}$ & Primary formation & Primary formation & Primary formation & Primary formation \\
\hline Marginal anlagen & Intrakinetally & Intrakinetally & De novo & Intrakinetally & Intrakinetally & Intrakinetally \\
\hline DK anlagen type ${ }^{\star}$ & $\begin{array}{l}\text { Mostly two-group type; } \\
\text { less commonly one } \\
\text { group }\end{array}$ & One-group type & One-group type & One-group type & One-group type & One-group type \\
\hline DK formation mode $\dagger$ & Secondary & Secondary & Primary & Secondary & Secondary & Secondary \\
\hline $\begin{array}{l}\text { Origin and process of } \\
\text { DK }\end{array}$ & $\begin{array}{l}\text { Within left parental } \\
\text { rows, followed by } \\
\text { fragmentation }\end{array}$ & $\begin{array}{l}\text { Within each of parental } \\
\text { one }\end{array}$ & $\begin{array}{l}\text { Within each of parental } \\
\text { one, no fragmentation }\end{array}$ & $\begin{array}{l}\text { As in lower } \\
\text { stichotrichs, no } \\
\text { fragmentation }\end{array}$ & $\begin{array}{l}\text { As in lower } \\
\text { stichotrichs }\end{array}$ & As in lower stichotrichs \\
\hline $\begin{array}{l}\text { Formation of caudal } \\
\text { cirri } \neq\end{array}$ & One & $\begin{array}{l}\text { One (mostly); two (in } \\
\text { few genera) }\end{array}$ & $\begin{array}{l}\text { Two (Dio., Uro.); one } \\
\text { (Eup.) }\end{array}$ & Two & Two & Two \\
\hline Sources of data & $\begin{array}{l}\text { Berger (1999); Song } \\
\text { (2004) }\end{array}$ & $\begin{array}{l}\text { Berger (2006); Song } \\
\text { (2004) }\end{array}$ & $\begin{array}{l}\text { Song \& Packroff (1993); } \\
\text { Song (2004); Song et al. } \\
(2004)\end{array}$ & Wicklow (1982) & Wicklow (1982) & Present work \\
\hline
\end{tabular}

* One group generates intrakinetally from the parental DK, the other is formed de novo dorsal-marginally.

$\dagger$ Initially as one group and then divides into two sets, one for each divider (primary mode) or initially as two groups for two daughter cells (secondary mode).

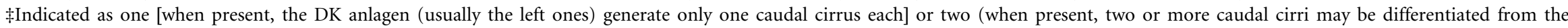
rightmost DK anlage). 


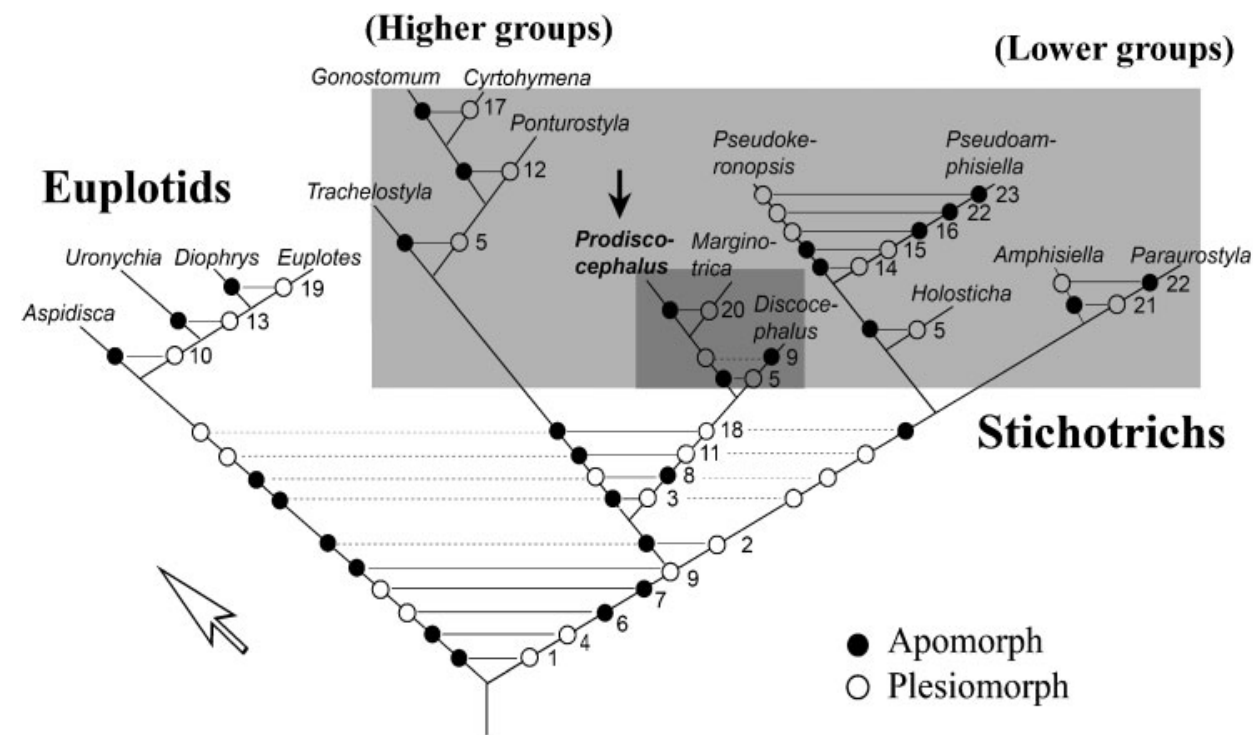

Spirotrichs

Fig. 7. Assessment of the phylogenetic position of $P$. borrori and some other representative stichotrichs-euplotids based on morphological and morphogenetic information. The light shaded area shows the stichotrichs and the dark shaded area shows the discocephalines. The arrow indicates the tentative evolutionary direction. See Table 2 for an explanation of the characters used.

Table 2. Morphogenetic and morphological characters on which the phylogenetic tree for representatives of discocephalines and other spirotrichous genera is based (Fig. 7)

Data were taken from Wicklow (1982), Song (1990, 2001), Jerka-Dziadosz \& Wiernicka (1992), Song \& Packroff (1993), Eigner \& Foissner (1994), Song et al. (1997, 2004), Berger (1999, 2006), Hu \& Song (2001) and Shao et al. $(2006,2007)$.

\begin{tabular}{|lll|}
\hline Character & \multicolumn{1}{c|}{ Apomorph } & \multicolumn{1}{c|}{ Plesiomorph } \\
\hline 1 & Formation of OP in opisthe in subapokinetal mode & In epi-apokinetal mode \\
2 & Number of cirral streaks stable & Variable in number \\
3 & Five-TC, five-cirrus-anlagen mode & Not five-TC, non-five-cirrus-anlagen mode \\
4 & UM in proter forms de novo from isolated anlage structure & Rebuilt within the old structure \\
5 & New OP formed in the proter & No new OP formed in the proter \\
6 & DK formed in secondary mode & In primary mode \\
7 & Cirri organized in groups or in patterns & Not in groups nor (generally) in patterns \\
8 & Formation of caudal cirri in euplotid mode & Not in euplotid mode \\
9 & Right marginal row absent & Present \\
10 & Left marginal row absent & Present \\
11 & DK not formed in each old row, often grouped & Intrakinetally in each old row \\
12 & One marginal row on each side & More than one on each side \\
13 & AZM in two parts & AZM in one part \\
14 & Frontoterminal cirri present & Absent \\
15 & Macronuclear nodules do not fuse into a single mass & Fusion into a single mass \\
16 & Midventral rows in typical zig-zag pattern & Two rows widely separated \\
17 & Cell with a distinctive 'head' or cephalized & Not cephalized \\
18 & FVT-cirral anlagen formed in secondary mode & In primary mode \\
19 & Two undulating membranelles & Single undulating membrane \\
20 & Ventral cirri sparsely distributed & Densely packed or aligned in a row(s) \\
21 & With one ventral cirral row & Several separated ventral rows \\
22 & Frontal cirri clearly differentiated & Not distinctly differentiated \\
23 & Caudal cirri present & Absent \\
\hline
\end{tabular}


over their precise systematic position (Corliss, 1979; Jankowski, 1979; Small \& Lynn, 1985; Tuffrau, 1986; de Puytorac et al., 1993; Lynn \& Small, 2000).

With reference to their morphology, discocephalines are conspicuously more similar to stichotrichs than to euplotids as follows: both left and right marginal rows are present (cf. only left marginal row present or neither of them present in euplotids); the body is flexible (cf. almost always rigid in euplotids); as in the lower stichotrichs, more than five transverse cirri are present (cf. invariably five in all typical euplotids); they have a relatively small buccal field, with Oxytricha-like undulating membranes [cf. generally having a conspicuously large buccal field with (mostly) a single undulating membrane in euplotids]; they possess many macronuclear nodules that are distributed sparsely throughout the cell (cf. usually one macronucleus or, if more than one, macronuclear nodules are closely aligned in euplotids).

Hitherto, morphogenesis has been described for only two discocephalines, Discocephalus ehrenbergi Dragesco, 1960 and Marginotricha faurei (Dragesco, 1963) Lin et al., 2004 (Dragesco, 1960; Lin et al., 2004). These, along with $P$. borrori, share several morphogenetic features of cortical development including: (i) stomatogenesis is of the epiapokinetal type; (ii) the caudal cirri derive from the rightmost DK anlagen, which are usually close to the right marginal fragment; (3) DK anlagen appear intrakinetally (secondary mode); (4) there are always more than five (number variable) FVT-anlagen that are formed in the primary mode; (5) the old AZM is either completely retained (e.g. D. ehrenbergi) or partly retained with the posterior portion renewed (e.g. M. faurei and P. borrori), but no new OP is generated (Wicklow, 1982; Foissner, 1996; Berger, 1999, 2006; Song, 2004).

The morphogenetic data reveal that the discocephalines have both stichotrich and hypotrich characteristics (Table 1). Five morphogenetic characters are highly characteristic of the stichotrichs: (i) the OP in the opisthe is generated de novo on the cell surface (epi-apokinetal mode); (ii) the two marginal rows are formed intrakinetally, which is typical for most stichotrichs; (iii) more than five FVT-cirral anlagen are formed, a plesiomorphic feature that is shared by the 'lower' stichotrichs; (iv) the new UM in the proter come from dedifferentiated old structures; (v) the dorsal anlagen are formed as two groups (i.e. secondary mode), one anterior and one posterior of the equatorial region. In contrast, there are only two morphogenetic features that are shared by discocephalines and euplotids to the exclusion of stichotrichs: (i) several caudal cirri are formed from the rightmost DK anlagen; (ii) the development of the FVT-anlagen is of the primary type, although this feature also occurs in some lower stichotrichs (Song et al., 1997; Song, 2004). On balance, therefore, the morphogenetic data suggest that the discocephalines are more closely related to the stichotrichs than to the hypotrichs.

Based on the molecular data derived from the complete SSU rDNA sequences, the discocephalines could be ancestral to the stichotrichs and other non-euplotid spirotrich lineages (Fig. 6). This is partly supported by the phylogenetic analyses using morphogenetic information, which suggests that Discocephalina might be an isolated stichotrich clade (Fig. 7).

Clearly, there are discrepancies in the position of discocephalines in the phylogenetic tress derived from morphological/morphogenetic data and molecular data (Figs 6 and 7) and, without doubt, both trees would benefit from an increase in the number of taxa included. In the meantime, and in the absence of any further data, we suggest that the discocephalines should have the taxonomic rank of order (i.e. Discocephalida Wicklow, 1982), as suggested by de Puytorac et al. (1993), within the subclass Stichotrichia.

\section{ACKNOWLEDGEMENTS}

This work was supported by the Natural Science Foundation of China (project nos 40676076 and 30670280), the Darwin Initiative Programme (project no. 14-015), which is funded by the UK Department for Environment, Food and Rural Affairs, and a grant from the Center of Excellence in Biodiversity, King Saud University. Thanks are also due to Dr Xiaozhong Hu, OUC, for kindly reading the first draft of this manuscript.

\section{REFERENCES}

Berger, H. (1999). Monograph of the Oxytrichidae (Ciliophora, Hypotrichia) (Monographiae Biologicae vol. 78). Dordrecht: Springer.

Berger, H. (2006). Monograph of the Urostyloidea (Ciliophora, Hypotricha) (Monographiae Biologicae vol. 85). Heidelberg: Springer.

Corliss, J. O. (1979). The Ciliated Protozoa: Characterization, Classification and Guide to the Literature, 2nd edn. New York: Pergamon.

Curds, C. R. \& Wu, I. C. H. (1983). A review of the Euplotidae (Hypotrichida, Ciliophora). Bull Br Mus Nat Hist (Zool) 44, 191-247.

de Puytorac, P., Batisse, A., Deroux, G., Fleury, A., Grain, J., LavalPeuto, M. \& Tuffrau, M. (1993). Proposition d'une nouvelle classification du phylum des protozoaires Ciliophora Doflein, 1901. $C R$ Acad Sci Paris 316, 716-720 (in French).

Dragesco, J. (1960). Ciliés mésopsammiques littoraux. Systématique, morphologie, écologie. Trav Stn Biol Roscoff (N S) 12, 1-356 (in French).

Dragesco, J. (1965). Ciliés mésopsammiques d'Afrique noire. Cah Biol Mar 6, 357-399 (in French).

Eigner, P. \& Foissner, W. (1994). Divisional morphogenesis in Amphisiellides illuvialis n. sp., Paramphisiella caudata (Hemberger) and Hemiamphisiella terricola Foissner and redefinition of the Amphisiellidae (Ciliophora, Hypotrichida). J Eukaryot Microbiol 41, 243-261.

Foissner, W. (1996). Ontogenesis in ciliated protozoa, with emphasis on stomatogenesis. In Ciliates, Cells as Organisms, pp. 95-177. Edited by K. Hausmann \& P. C. Bradbury. Stuttgart: Gustav Fischer.

Hu, X. \& Song, W. (2001). Morphology and morphogenesis of Holosticha heterofoissneri nov. spec. from the Yellow Sea, China (Ciliophora, Hypotrichida). Hydrobiologia 448, 171-179.

Jankowski, A. W. (1979). Revision of the order Hypotrichida Stein, 1859. Generic catalogue, phylogeny, taxonomy. Akad Nauk SSSR Zool Inst Trudy 86, 46-85 (in Russian). 
Jerka-Dziadosz, M. \& Wiernicka, L. (1992). Ultrastructural studies on the development of cortical structures in the ciliary pattern mutans of the hypotrich ciliate Paraurostyla weissei. Eur J Protistol 28, 258-272.

Kumar, S., Tamura, K. \& Nei, M. (2004). MEGA3: integrated software for molecular evolutionary genetics analysis and sequence alignment. Brief Bioinform 5, 150-163.

Li, L. \& Song, W. (2006). Phylogenetic position of the marine ciliate, Certesia quadrinucleata (Ciliophora; Hypotrichida) inferred from the complete small subunit ribosomal RNA gene sequence. Eur J Protistol 42, 55-61.

Lin, X., Song, W. \& Warren, A. (2004). Redescription of the rare marine ciliate, Prodiscocephalus borrori (Wicklow, 1982) from shrimp-culturing waters near Qingdao, China, with redefinitions of the genera Discocephalus, Prodiscocephalus and Marginotricha (Ciliophora, Hypotrichida, Discocephalidae). Eur J Protistol 40, 137-146.

Lynn, D. H. \& Small, E. B. (2000). Phylum Ciliophora Doflein, 1901. In An Illustrated Guide to the Protozoa, 2nd edn, pp. 371-656. Edited by J. J. Lee, G. F. Leedale \& P. Bradbury. Lawrence, KS: Society of Protozoologists and Allen Press.

Nixon, K. C. (1999). The Parsimony Ratchet, a new method for rapid parsimony analysis. Cladistics 15, 407-414.

Nylander, J. (2004). MrModeltest v. 2. Uppsala: Evolutionary Biology Centre, Uppsala University.

Posada, D. \& Crandall, K. A. (1998). Modeltest: testing the model of DNA substitution. Bioinformatics 14, 817-818.

Ronquist, F. \& Huelsenbeck, J. P. (2003). MrBayes 3: Bayesian phylogenetic inference under mixed models. Bioinformatics 19, 1572-1574.

Schlegel, M., Elwood, H. J. \& Sogin, M. L. (1991). Molecular evolution in hypotrichous ciliates: sequence of the small subunit RNA genes from Onychodromus quadricornutus and Oxytricha granulifera (Oxytrichidae, Hypotrichida, Ciliophora). J Mol Evol 32, 64-69.

Shao, C., Song, W., Warren, A., Al-Rasheid, K., Yi, Z. \& Jun, G. (2006). Morphogenesis of the marine ciliate, Pseudoamphisiella alveolata (Kahl, 1932) Song \& Warren, 2000 (Ciliophora, Stichotrichia, Urostylida) during binary fission. J Eukaryot Microbiol 53, 388-396.

Shao, C., Song, W., Yi, Z., Gong, J., Li, J. \& Lin, X. (2007) Morphogenesis of the marine spirotrichous ciliate, Trachelostyla pediculiformis (Cohn, 1866) Borror, 1972 (Ciliophora, Stichotrichia), with consideration of its phylogenetic position. Eur J Protistol 43, 255-264.

Sikes, D. S. \& Lewis, P. O. (2001). PAUPRat: PAUP implementation of the parsimony ratchet. Beta software, version 1. Storrs, CT: Department of Ecology and Evolutionary Biology, University of Connecticut.

Small, E. B. \& Lynn, D. H. (1985). Phylum Ciliophora Doflein, 1901. In An illustrated Guide to the Protozoa. Society of Protozoologists, pp. 393-575. Edited by J. J. Lee, S. H. Hutner \& E. C. Bovee. Lawrence, KS: Allen Press.

Sogin, M. L. \& Elwood, H. J. (1986). Primary structure of the Paramecium tetraurelia small-subunit rRNA coding region: phylogenetic relationships within the Ciliophora. J Mol Evol 23, 53-60.

Song, W. (1990). A comparative analysis of the morphology and morphogenesis of Gonostomum strenua (Engelmann, 1862) (Ciliophora, Hypotrichida) and related species. J Eukaryot Microbiol 37, 249-257.

Song, W. (2001). Morphology and morphogenesis of the marine ciliate, Ponturostyla enigmatica (Dragesco \& Dragesco-Kernéis) Jankowski, 1989 (Ciliophora, Hypotrichida, Oxytrichidae). Eur J Protistol 37, 181-197.

Song, W. (2004). On cell development of ciliated protozoa: diversity and progress. J Ocean Univ China 34, 747-757 (in Chinese with English summary).

Song, W. \& Packroff, G. (1993). Beitrag zur Morphogenese des marinen Ciliaten Diophrys scutum (Dujardin, 1841) (Ciliophora, Hypotrichida). Zool Jahrb Anat 123, 85-95 (in German).

Song, W., Warren, A. \& Hu, X. (1997). Morphology and morphogenesis of Pseudoamphisiella lacazei (Maupas, 1883) Song, 1996 with suggestion of establishment of a new family Pseudoamphisiellidae nov. fam. (Ciliophora, Hypotrichida). Arch Protistenkd 147, 265-276.

Song, W., Wilbert, N., Chen, Z. \& Shi, X. (2004). Considerations on the systematic position of Uronychia and related euplotids based on the data of ontogeny and 18S rRNA gene sequence analyses, with morphogenetic redescription of Uronychia setigera Calkins, 1902 (Ciliophora, Euplotida). Acta Protozool 43, 313-328.

Swofford, D. L. (2002). PAUP*: Phylogenetic analysis using parsimony (and other methods), version 4. Sunderland, MA: Sinauer Associates.

Thompson, J. D., Higgins, D. G. \& Gibson, T. J. (1994). CLUSTAL W: improving the sensitivity of progressive multiple sequence alignment through sequence weighting, position-specific gap penalties and weight matrix choice. Nucleic Acids Res 22, 4673-4680.

Tuffrau, M. (1986). Proposition d'une classification nouvelle de l'Ordre Hypotrichida (Protozoa, Ciliophora), fondée sur quelques données récentes. Ann Sci Nat 8, 111-117 (in French).

Tuffrau, M. \& Fleury, A. (1994). Classe des Hypotrichea Stein, 1859. Trop Zool 2, 83-151 (in French).

Vos, R. A. (2003). Accelerated likelihood surface exploration: the likelihood ratchet. Syst Biol 52, 368-373.

Wicklow, B. J. (1982). The Discocephalina (n. subord.): ultrastructure, morphogenesis and evolutionary implications of a group of endemic interstitial hypotrichs (Ciliophora, Protozoa). Protistologica 18, 299-330.

Wilbert, N. (1975). Eine verbesserte Technik der Protargolimprägnation für Ciliaten. Mikrokosmos 64, 171-179 (in German). 